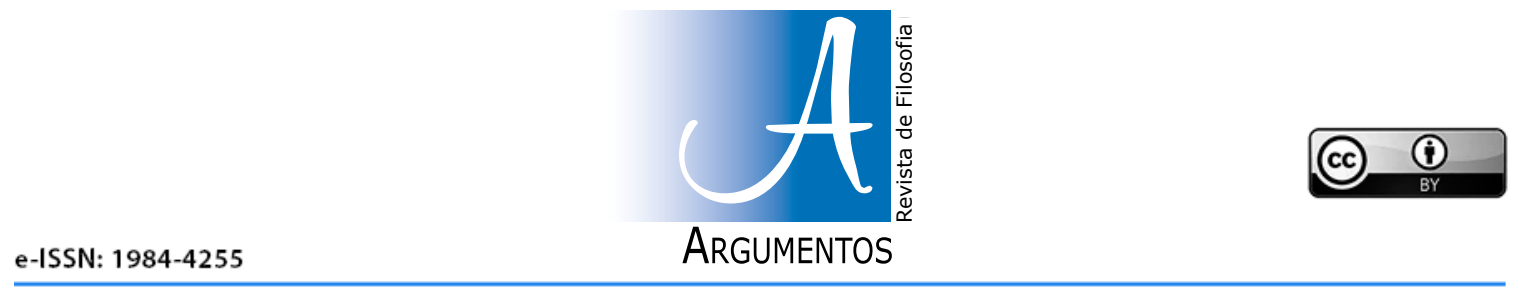

D0I: $10.36517 /$ Argumentos.25.14

\title{
Linguagem e metafísica em João Guimarães Rosa
}

\section{Language and metaphysics in João Guimarães Rosa}

\author{
Roberto Antônio Penedo do Amaral \\ http://orcid.org/0000-0002-4426-9439 - E-mail: robertoamaral001@gmail.com
}

\begin{abstract}
RESUMO
O artigo se propõe a problematizar a linguagem e a metafísica do escritor mineiro João Guimarães Rosa (1908-1967) como o seu modo de habitar a filosofia ou filosofar. Para tanto, é estabelecido um diálogo com o filósofo dinamarquês Søren Kierkegaard (1813-1855) e com o pensador espanhol Miguel de Unamuno (1864-1936), cujas linguagens que utilizam para a construção de seus respectivos pensamentos especulativos, segundo o escritor, não os tornam filósofos sistemáticos, e, sim, metafísicos da alma humana e da transcendência. O foco de discussão está pautado na análise das declarações de Rosa, colhidas em conversa com o crítico literário Günter W. Lorenz, e nas correspondências entretidas com seu tradutor alemão Curt Meyer-Clason e com seu tradutor italiano Edoardo Bizzari.
\end{abstract}

Palavras-chave: Linguagem. Metafísica. Filosofia. João Guimarães Rosa. Søren Kierkegaard. Miguel de Unamuno.

\begin{abstract}
The article proposes to problematize the language and metaphysics of the Minas Gerais writer João Guimarães Rosa (1908-1967) as his way of inhabiting philosophy or philosophizing. To this end, a dialogue is established with the Danish philosopher Søren Kierkegaard (1813-1855) and with the Spanish thinker Miguel de Unamuno (1864-1936), whose languages they use to construct their respective speculative thoughts, according to the writer, do not make them systematic philosophers, but rather metaphysicians of the human soul and of transcendence. The focus of discussion is based on the analysis of Rosa's statements, collected in conversation with the literary critic Günter W. Lorenz, and in the correspondence with his German translator Curt Meyer-Clason and his Italian translator Edoardo Bizzari.
\end{abstract}

Keywords: Language. Metaphysics. Philosophy. João Guimarães Rosa. Søren Kierkegaard. Miguel de Unamuno. 
A filosofia é a maldição do idioma. Mata a poesia, desde que não venha de Kierkegaard ou Unamumo, mas então é metafísica.

João Guimarães Rosa

\section{"A filosofia é a maldição do idioma. Mata a poesia"}

Meu primeiro encontro com Guimarães Rosa se deu no ano de 1996. Melhor seria admitir que o referido encontro foi também o meu primeiro encanto com essa figura que, segundo meu singelo ponto de vista, é o maior escritor da literatura brasileira de todos os tempos, ombreando de forma arrojada os/as grandes da literatura estrangeira. Se meu primeiro encanto com Rosa se deu na referida data, significa que sou um leitor tardio de sua irrepetível obra, cuja inauguração em minha vida realizou-se com a leitura do conto que julgo como o mais belo já escrito na história da literatura universal: A terceira margem do rio (ROSA, 2001, p. 79-85). Ler essa primeira curta estória de Rosa imprimiu uma marca inextinguível em meu pensamento, em meu sentimento e, porque não dizer, em meu corpo inteiro, posto que a um encontro que nos mobiliza tão profundamente, nunca vamos pela metade, mas íntegros, completos, absolutos. E não foi de outra forma que a escrita de Rosa me alcançou pela vez primeira, senão rascante e turbulenta.

A despeito desse irruptivo encontro com a lavra rosiana, levei ainda longos sete anos para me haver a sério com a literatura do alquimista da palavra de Cordisburgo ${ }^{1}$, mais precisamente em 2003, quando me preparava para o doutorado, e tive a oportunidade de realizar a leitura de todos os seus livros, em especial de Grande sertão: veredas (GSV) (1956), que elegi como foco de meus estudos e de minhas pesquisas. Desde então, lá se vão dezessete anos de dedicação quase obsessiva à obra de maior vulto de Rosa, que culminou na minha tese doutoral: A teofania em Grande sertão: veredas - por uma pedagogia dos símbolos (AMARAL, 2007), e em alguns artigos e ensaios: 'Viver é muito perigoso' ou o 'mal' em Grande sertão: veredas - breves anotações tomistas (AMARAL, 2006a); O imaginário em Grande sertão: veredas - a travessia do Liso do Sussuarão (AMARAL, 2006b); As aparências de Cronos em Grande sertão: veredas (AMARAL, 2011a); A questão do narrador: Walter Benjamin e Guimarães Rosa (AMARAL, 2011b); A inovação semântica ricoeuriana em Grande sertão: veredas (AMARAL, 2013); Todos os homens são filósofos. Riobaldo é homem. Logo Riobaldo é filósofo (AMARAL, 2016a); A narrativa rosiana: o verbo do sertão (AMARAL, 2016b); A questão do mal em Grande Sertão: Veredas - um diálogo entre Tomás de Aquino e o jagunço Riobaldo (AMARAL, 2016c); Guimarães Rosa e Marcuse: a literatura como resistência política (AMARAL, 2019) e A questão do mal em Grande sertão: veredas - uma leitura à luz da hermenêutica de Paul Ricoeur (AMARAL, 2019).

Mais recentemente, outra vez me lancei à releitura interpretativa de GSV, quando do meu estágio pós-doutoral resultou o ensaio "Veredazinhas eleitas - rasuras lacanianas em Grande sertão: veredas" (AMARAL, 2020). Para um leitor tardio da obra rosiana, portanto, penso que já seja hora de perdoar a mim mesmo pelo fato de não ter começado a lê-la bem antes do que deveria. A devoção quase religiosa que tenho dedicado a Rosa e aos seus escritos, ao longo

\footnotetext{
1 Cidade natal do mineiro Guimarães Rosa. Nas palavras de Vicente Guimarães (1972, p. 3), seu tio, "ao inaugurar-se lá a estação da Central do Brasil, o povoado [Coração de Jesus da Vista Alegre], pelo decreto estadual no 99, de 9 de junho de 1890, foi elevado à categoria de distrito, com o definitivo apelido de Cordisburgo, formado e sugerido pelo Padre João do Santo Antônio. Cordis coração; burgo - lugar, cidade. De nome mudado, o arraial continuou sendo o 'burgo do coração"'.
} 
de quase vinte anos, já tem compensado boa parte do período em que eu não o conhecia por meio de sua prodigiosa e aplicada pluma literária. Bem demonstra isso o fato de eu estar aqui, mais uma vez, diante de várias páginas em branco que vão aos poucos sendo preenchidas por palavras convertidas em dádivas, na ânsia de abater a ainda enorme dívida que tenho para com ele, uma dívida que, com absoluta certeza, nunca irei quitar.

Gostaria de esclarecer, desse modo, que não foi por exibicionismo que enumerei os textos que escrevi, derivados das leituras, estudos e pesquisas que realizei sobre a obra do escritor mineiro. Na realidade, estou muito distante da vasta produção acadêmica e de crítica literária realizada por vários/as outros/as leitores/as da literatura rosiana. Os meus objetivos, ao assim proceder, são bem mais modestos. Em primeiro lugar, quis demonstrar que, embora seja um leitor temporão de Rosa, o fato de ter escrito vários textos sobre seus livros, principalmente sobre GSV, me assegurou um nível de intimidade com seu labor literário que me permitiu tê-lo como um autor-próximo, ousaria mesmo dizer como um autor-amigo, e não como um autor-estranho ou um autor-distante. $E$, se tratando de Rosa, isso não é pouca coisa, modéstia à parte, naturalmente. Em segundo lugar, ter enumerado os meus escritos que tratam de diversos temas presentes na narrativa rosiana, predominantemente em GSV, me dá a oportunidade de introduzir-me na temática desafiadora que a mim foi lançada pelo título deste dossiê: Filosofia brasileira. Em outras palavras, até o presente momento, com exceção do ensaio A narrativa rosiana: o verbo do sertão (AMARAL, 2016b), no qual busquei apresentar uma discussão sobre a presença de elementos metafísico-religiosos nas principais obras de Rosa, todos os demais textos que escrevi tiveram o romance, as novelas e os contos do escritor mineiro como objetos de estudo, a partir do pressuposto teórico e conceitual de um determinado pensador ligado ou à filosofia, ou à antropologia, ou à psicanálise. Porém, o exercício requerido por este artigo é o de tomar o próprio Guimarães Rosa como um pensador, mais especificamente, como um pensador que estaria de alguma maneira fronteiriço à figura do filósofo. Eis o desafio paradoxal, já bem evidenciado pelo próprio escritor na epígrafe que escolhi para este artigo: "A filosofia é a maldição do idioma. Mata a poesia, desde que não venha de Kierkegaard ou Unamumo, mas então é metafísica" (ROSA apud LORENZ, 1973, p. 324), colhida em conversa entabulada por Rosa e o crítico literário alemão Günter W. Lorenz, em 1965, por acaso, o ano de meu nascimento. Para evidenciar ainda mais o paradoxo, destaco um detalhe que só aumenta a minha dificuldade no trato da provocação a que fui lançado. Antes de Rosa fazer sua contundente declaração sobre a filosofia, Lorenz havia-Ihe feito a seguinte pergunta: "Você tem alguma coisa contra os filósofos?" (ROSA apud LORENZ, 1973, p. 324). Sem titubear, o autor de GSV respondeu: "Tenho" (ROSA apud LORENZ, 1973, p. 324).

Como motivo condutor do referido desafio paradoxal que, para o mal ou para o bem, optei por aceitar, partirei dos próprios elementos de discussão que a epígrafe oferece.

Afinal de contas, por que Rosa afirma que "a filosofia é a maldição do idioma"? A minha melhor hipótese é a de que ele esteja se referindo à filosofia enquanto um sistema de pensamento que busca, de uma forma enciclopédica, dar resposta a todos os dilemas enfrentados pela condição humana. Tal filosofia sistemática não daria espaço para a inventividade, para a criatividade, enfim, para outros modos de pensamento que não estejam submetidos a um regramento lógico e epistemológico, no sentido de ensaiar outras e novas possibilidades de reflexão e de meditação sobre as inúmeras perplexidades humanas. Em razão disso, penso eu, é que o escritor mineiro decreta que tal filosofia "Mata a poesia", pois abre mão de um diálogo profícuo com a fecundidade imaginativa, ou seja, com a dimensão poética, inconsciente, transcendente e, até mesmo irracional do humano, conforme ele ressaltou em missiva dirigida ao seu tradutor italiano Edoardo Bizzarri: "como eu, os meus livros, em essência, são 'anti-inte- 
lectuais' - defendem o altíssimo primado da intuição, da revelação, da inspiração sobre o bruxolear presunçoso da inteligência reflexiva, da razão, da megera cartesiana" (ROSA, 2003b, p. 90). Rosa realizou um revigoramento da língua brasileira mediante recursos linguísticos os mais diversos, a ponto de se distinguir o conjunto de sua obra como a "literatura de um homem" (LORENZ, 1973, p. 316), no sentido de ele ter criado um microcosmo ficcional ímpar - o Sertão - que anela com todo um universo transcendente, atinente à sua própria descrição de que "este pequeno mundo do sertão, este mundo original e cheio de contrastes, é para mim o símbolo, diria mesmo o modelo de meu universo" (ROSA apud LORENZ, p. 322). Um escritor advindo de tal cepa não poderia ter outro propósito além do de buscar alcançar o humano em sua condição mais atípica e singular. Em seus próprios termos, ele afirma que "sua missão mais importante: é o próprio homem" (LORENZ, 1973, p. 318), tarefa essa que uma filosofia sistemática está muito longe de cumprir.

Não foi, por conseguinte, trafegando a epiderme da linguagem que Rosa buscou realizar tão complexa missão, senão lapidando-a, esmerando-a com requinte de detalhes enigmáticos. Segundo suas próprias palavras:

A excessiva iluminação, geral, só no nível do raso, da vulgaridade. Todos os meus livros são simples tentativas de rodear e devassar um pouquinho o mistério cósmico, esta coisa movente, impossível, perturbante, rebelde a qualquer lógica, que é a chamada 'realidade', que é a gente mesmo, o mundo, a vida. Antes o obscuro que o óbvio, que o frouxo. Toda lógica contém inevitável dose de mistificação. Toda mistificação contém boa dose de inevitável verdade. Precisamos também do obscuro (ROSA, 2003a, p. 238).

Ao forjar um renovo da língua, por meio de estratagemas nunca antes experimentados por outros/as escritores/as, tornou-a mais expressiva, desprendendo-a de seu uso vulgar e cotidiano, pois que, para ele, "Somente renovando a língua é que se pode renovar o mundo" (ROSA apud LORENZ, p. 345). Com tal laboriosa escrita, o escritor mineiro construiu, de acordo com o que se pode confirmar em missiva entretida com seu tradutor alemão Curt Meyer-Clason, um monumento de "literatura-vida" (ROSA, 2003b, p. 8), predispondo os/as seus/suas leitores/as "novas maneiras de sentir e de pensar" (ROSA, 2003b, p. 8).

\section{“... desde que não venha de Kierkegaard..."}

Embora tenha "alguma coisa contra os filósofos", Rosa aceita de bom grado certo tipo de especulação criada por esses amigos da sabedoria, como é o caso de "Kierkegaard ou Unamuno". Penso que neste ponto de minha escrita seja necessário fazer uma breve digressão para tentar entender o porquê de Rosa, particularmente, dar boa acolhida a esses dois pensadores.

Em relação ao Søren Kierkegaard, a minha suspeita da antipatia de Rosa à sistematicidade filosófica se confirma, a julgar pela coincidência com o modo de pensar do filósofo dinamarquês sobre o assunto. A tese $O$ conceito de ironia constantemente referido a Sócrates defendida em 1841, por exemplo, se constituiu no seu "primeiro arrazoado existencial em defesa da subjetividade, dirigido sobretudo contra a filosofia em voga em seu tempo, isto é, o hegelianismo" (KEMP, 2001, p. 566). De forma irônica, na referida tese, o pensador dinamarquês pôs em questão a filosofia do Herr Georg W. F. Hegel (1770-1831), que buscou engendrar um "gigantesco sistema do mundo, uma enorme elucidação do absoluto [...]" (D'HONT, 2001, p. 472). Além disso, Rosa certamente deve ter se entusiasmado com os escritos de Kierkegaard por eles se constituírem no esforço de estabelecer um diálogo engenhoso e fecundo na busca por ultrapassar os limites entre a literatura, a filosofia e a teologia, manifestando o desejo do pensador 
dinamarquês "de criar todo um universo poético e filosófico capaz de exprimir sua própria experiência em diferentes níveis da vida e conferir-lhe uma linguagem para compreender a si mesmo" (KEMP, 2001, p. 566).

Nesses termos, para Kierkegaard, assim como para Rosa, expressões como experiência, vida e compreensão de si mesmo não são alcançáveis em sua profundidade pela via de um conhecimento que se apresenta como uma resposta pronta e acabada para a complexidade do humano, como ambiciona uma filosofia sistemática. Contra esse tentame, no volume $X$ de suas Obras completas, o filósofo de Copenhague denuncia que "a desgraça de nossa época são o excesso de saber e o esquecimento da existência e da interioridade" (KIERKEGAARD apud KEMP, 2001, p. 567). Para fundamentar essa denúncia, acrescento um trecho do que ele escreveu no volume I de seus Papeis: "Trata-se de encontrar uma verdade que seja verdade para mim, de encontrar a ideia pela qual quero viver e morrer" (KIERKEGAARD apud KEMP, 2001, p. 567). Numa palavra, para Kierkegaard os filósofos que defendem a filosofia enquanto um conhecimento sistemático, pensam o mundo e os humanos que o habitam desde um invólucro que os encerra em si mesmos, em conformidade com a convicção de que a verdade está necessariamente vinculada tão somente à realidade objetiva. Porém, pensar o mundo e o humano, em termo de existência, de vida e de experiência é tomá-los desde uma perspectiva subjetiva que preconiza ruptura, rompimento, autodeterminação, liberdade. Em outros termos, para o pensador dinamarquês, a "incerteza objetiva, mantida na apropriação da interioridade mais apaixonada, é a verdade, a mais alta verdade que possa haver para um existente" (KIERKEGAARD apud KEMP, 2001, p. 571). E acrescenta:"o como subjetivo precede e até resolve o quê objetivo" (KIERKEGAARD apud KEMP, 2001, p. 571). Por meio de vários enfoques, em termos de linguagem, é que Kierkegaard procura esboçar cada haver da existência e dos dilemas que ela impõe, de modo a pôr em causa os abismos a serem superados, "para, afinal, dar o salto por excelência que separa a lógica filosófica do absurdo religioso ou os liga a ambos" (KEMP, 2001, p. 568).

No meu modo de ver, o salto proposto por Kierkegaard, que transpõe a fronteira entre o poético, o filosófico e o teológico, entre a realidade objetiva e a realidade subjetiva com o fito de alcançar a verdade da vida, da existência e da experiência humana, se aproxima da ideia de paradoxo como concebida por Rosa, a saber:

a vida, a morte, tudo é, no fundo, paradoxo. Os paradoxos existem para que ainda se possa exprimir algo para o qual não existem palavras. Por isso, acho que um paradoxo bem formulado é mais importante que toda a matemática, pois ela própria é um paradoxo, porque cada fórmula que o homem pode empregar é um paradoxo (ROSA apud LORENZ, 1973, p. 324).

Desde tal paradoxo, ou seja, desde essa expressão para a qual ainda não foram inventadas palavras é que Kierkegaard vê a verdade da vida escapar ao pensamento enquanto sistema. Para ele, essa verdade não é uma verdade a ser buscada e encontrada pelo/a pensador/a, mas uma verdade que o/a surpreende, que o/a flagra de forma extraordinária e extemporânea, "no piscar de olhos, como paradoxo impensado e impensável [...], o religioso que o pensamento aspira mas que não pode alcançar" (KEMP, 2001, p. 570). Pelo viés kierkegaardiano, que soa como um manifesto tenaz contra a Razão do Sistema, "a subjetividade é a não-verdade" (KIERKEGAARD apud KEMP, 2001, p. 572). A versão rosiana sobre o assunto talvez se resumisse na seguinte ironia: "Não devemos examinar a vida do mesmo modo que um colecionador de insetos contempla seus escaravelhos" (ROSA apud LORENZ, 1973, p. 323).

Daí a necessidade inelutável de o humano, em sua condição de existente ímpar e inigualável, criar modos de expressão para além dos já disponíveis, tornados, na maioria das vezes, 
em ultrapassados jargões e em exauridos lugares-comuns, inteiramente esvaziados de sentido e significado. No julgamento de Rosa, "O que chamamos hoje linguagem corrente é um monstro morto. A língua serve para expressar ideias, mas a linguagem corrente expressa apenas clichês e não ideias; por isso está morta, e o que está morto não pode engendrar ideias" (ROSA apud LORENZ, 1973, p. 345). Sobre tais modos de expressão que teimam em engendrar ideias, terei muito a dizer, quando estiver tratando do enredado modo de Rosa lidar com a linguagem que culmina em sua peculiar metafísica.

\section{“... ou Unamuno,"}

Rosa não teria estranhado a minha perplexidade, ao folhear o Dicionário dos Filósofos (HUISMAN, 2001) em busca do verbete "Unamuno" e não o ter encontrado, já que o mencionado dicionário se constitui numa obra de referência para estudos e pesquisas sobre os pensadores fundamentais da história da filosofia, organizada pelo esteta francês Denis Huisman. Qual a razão de o pensador, escritor e ensaísta espanhol Miguel de Unamuno ter sido excluído do rol dos/as grandes nomes que habitam o panteão da glória filosófica? A resposta mais simples que se poderia dar a essa pergunta é a de que o organizador da obra, diante da dificuldade de incluir todos/as os/as filósofos/as de que se tem notícia, optou em fazer escolhas, segundo critérios que ele julgou mais pertinentes e relevantes. No entanto, ao ler a introdução do dicionário, notei uma curiosa nota de rodapé do editor brasileiro, que, não posso negar, me deixou deveras frustrado: "Esta introdução não leva em conta, evidentemente, os cortes feitos na presente edição brasileira, para a qual foi feita uma seleção mantendo apenas os nomes mais significativos com o objetivo de reduzir o volume da obra, tornando-a viável para o nosso mercado" (CONCHE, 2001. p. XIV. Grifos meus). Não sei se o verbete "Unamuno" figura na letra U do dicionário original. Para o meu azar, sei apenas que, por questões "mercadológicas", Unamuno não é um filósofo suficientemente "significativo" para constar na edição do Dicionário dos filósofos publicada no Brasil.

Porém, não vou me ater em discutir as mesquinharias impostas pelo sistema capitalista que impede, não em rara vez, o autêntico e pleno usufruto, o desfrute, o gozo de criações intelectuais e artísticas, mediante suas indefectíveis "razões de mercado". Até porque o motivo da exclusão ${ }^{2}$ de Unamuno da cidadela dos/as filósofos se encontra, me parece, sob uma perspectiva mais natural, e porque não dizer, até mais desejável, conforme se pode constatar pelo posicionamento de Fernando Savater, da atual filosofia espanhola: "A Unamuno coube a glória, disso não há dúvida, mas não feita de admiração sem mácula e reconhecimento pleno; sua glória é litigiosa, pugnaz, pródiga em ironia e escândalo, em dúvidas e reconvenções"(SAVATER, 1996, p. VII).

Rosa, no entanto, é mais incisivo e objetivo que a complacente retórica de Savater em relação ao pensador espanhol, conforme uma réplica que recolhi da longa conversa que o escritor mineiro manteve com Lorenz, já referida neste artigo: “Unamuno não era um filósofo; sempre se equivocam, referindo-se a ele nesse sentido. Unamuno foi um poeta da alma; criou da linguagem a sua própria metafísica pessoal. É uma importante diferença com relação aos chamados filósofos" (ROSA, 1973, p. 324).

\footnotetext{
${ }^{2}$ A referida exclusão de Unamuno talvez se dê pela forma controversa e ambígua de como seus escritos figuravam para seus críticos, conforme polemiza Savater (1996, p. VIII: "Para os que o têm antes de tudo como ensaísta sua poesia é muito secamente conceitual; os que o decretam poeta denunciam seus ensaios demasiados caprichos líricos; seus romances e suas peças teatrais são muito'filosóficas' ou vagamente 'poéticas"'.
} 
Com essa afirmação, Rosa dá provas de que foi um leitor invulgar do pensador espanhol, pois se há algo que se pode afirmar sobre ele, e que faz com que também seja possível aproximá-lo do pensamento de Kierkegaard, é que, ao longo de sua obra ficcional, Unamuno teve sempre uma inquietação fundamental: "¿es posible la transcendência individual?" (MIRAMÓN, 1986, p. 7). Além disso, se Unamuno optou pela ficção é porque percebeu que por meio de tal gênero literário encontrou uma via de expressão de seu pensamento "no meramente intelectual y retórico, más bien al contrario, ganó presencia em la encarnadura de sus criaturas de ficción" (MIRAMÓN, 1986, p. 7).

A confirmação dessa citação vem do próprio Unamuno que alegava ser a genuína e sincera filosofia espanhola, por exemplo, não a que se apresentava na forma de sistemas de pensamento, mas a que se expunha de maneira fragmentada nas grandes obras literárias, como é o caso de Dom Quixote de La Mancha (1605) de Miguel de Cervantes (1547-1616) e de La vida es sueño (1635) de Pedro Calderón de La Barca (1600-1681). Em seus próprios termos, eis o que assevera o reitor de Salamanca: "Nuestra filosofia, si así puede llamarmarse, rebasa de casilleros lógicos: hay que buscarla encarnada em sucesos de ficción y em imágenes de bulto" (UNAMUNO apud MIRAMÓN, p. 7). Assim como em Kierkegaard, os escritos de Unamuno são um compósito de filosofia, literatura e teologia que estabelece pautas estéticas, éticas e metafísicas.

Pode-se dizer que os eixos fundamentais do conjunto da obra unamoniana estão consubstanciados nos pares vida-sonho e mundo-teatro, por intermédio dos quais o pensador nascido em Bilbao formula sua filosofia, sua literatura e, porque não dizer, sua inaudita teologia, revestida numa espécie de estética da religião para a qual o sentido de sonhar, para o humano, implica em acordar para a verdadeira realidade transcendente: Deus. É possível perceber a profundidade e a complexidade do par vida-sonho na seguinte citação:

¿No es acaso todo esto un sueño de Dios o de quien sea, que se desvanecerá em cuanto Él despierte, y por eso le rezamos y elevamos a Él cânticos e himnos, para adormecerle, para acunar su sueño? ¿No es acaso la liturgia toda la de todas las religiones un modo de brezar el sueño de Dios y que no despierte y deje de soñarnos? (UNAMUNO apud MIRAMÓN, 1986, p. 9-10).

E é justamente do par vida-sonho que se constitui o par mundo-teatro, posto que, se a vida humana é um sonho de Deus, o fato de o humano vivê-la nada mais é que cumprir um papel previamente escrito, assim como um ator desempenha no palco o personagem que lhe foi destinada pelo dramaturgo, de acordo com o que aduz o pensamento unamoniano: "Los que vivimos la sentencia calderoniana de que la vida es sueño sentimos también la shakespeariana de que estamos hechos de la estopa misma de los sueños, que somos um sueño de Dios y que nuestra historia es la que por nosotros Dios sueña" (UNAMUNO apud MIRAMÓN, 1986, p. 10).

Na mesma conversa empreendida com Rosa, Lorenz, em determinado momento, por conta da proximidade que percebe entre o modo de pensar do autor de GSV e o do autor de Niebla (1914/1986), chega a nomeá-lo de "o Unamuno do sertão" (LORENZ, 1973, p. 324), ao que, demasiado envaidecido, o escritor mineiro acrescenta: "Unamuno, sim! Unamuno poderia ter sido o meu avô. Dele herdei minha fortuna: meu descontentamento" (ROSA apud LORENZ, 1973, p. 324). E que descontentamento seria esse que Rosa tanto enaltece e que teria herdado do pensador espanhol? A princípio, o reconhecimento de que o que é inerente ao humano é posicionar-se contra o óbvio, contra o corrente, colocando em xeque o acontecimento que "converte uma possibilidade livre em necessidade" (SAVATER, 1996, p. XVII). Ao mesmo tempo, não se conformar com as palavras em estado de dicionário, mas confrontá-las de forma obsessiva até que confessem a verdade que lhes subjazem. O pensador espanhol, por meio de um 
labor diligente e incansável, buscava arrancar o mistério que as palavras escondiam nas coisas que por elas eram nomeadas, pois, para ele, "por la palavra, por el verbo es todo lo que es" (UNAMUNO apud MIRAMÓN, 1986, p. 10). Numa passagem de GSV, Riobaldo, o narrador personagem faz ecoar essa divisa unamuniana quando declara: "O que é pra ser - são as palavras!" (ROSA, 2001. p. 64). Para se ter uma ideia do mérito que Unamuno atribuía ao burilamento das palavras, basta ter em conta que, desde o seu modo de ver e crer, ou melhor, desde sua transcendência individual, elas eram mais importantes do que as coisas criadas pelo humano, pois "Cuando se hace algo no queda el hecho, sino la hacedora, la palavra. Que la palavra fue al principio y será al fin. ¡Dejar un nombre! Es todo lo que hay de dejar; um nombre que viva eternamente. Lo demás, son huesos" (UNAMUNO apud MIRAMÓN, 1986, p. 10).

Por sua vez, Rosa, dando azo à sua condição de "neto" de Unamuno por adoção e ao seu legado de descontentamento com a palavra sem vitalidade, reverbera o mesmo anseio pela transcendência da linguagem, como apregoado pelo pensador espanhol, ao fazer a seguinte confissão a Lorenz:

Nunca me contento com alguma coisa. Como lhe revelei, estou buscando o impossível, o infinito. $E$, além disso, quero escrever livros que depois de amanhã não deixem de ser legíveis. Por isso acrescentei à síntese existente a minha própria síntese, isto é, incluí em minha linguagem muitos outros elementos, para ter ainda mais possibilidade de expressão (ROSA apud LORENZ, 1973, p. 338).

Sobre tais possibilidades de expressão e como elas se constituíram por meio de uma linguagem incomum na literatura de um "homem do sertão" (ROSA apud LORENZ, 1973, p. 321), a ponto de ele assumi-la como seu "elemento metafísico" (ROSA apud LORENZ, 1973, p. 337), e, fundamentalmente, se esse elemento metafísico faz de Rosa um escritor que bordeja a filosofia, são questões que buscarei problematizar nos próximos tópicos deste artigo.

\section{“... mas então é metafísica"}

Entre as várias correspondências entretidas com Bizzarri, uma se destaca pelo fato de Rosa, sem constrangimento, valorar hierarquicamente os aspectos que, enquanto autor, gostaria que os/as seus/as leitores/as atentassem ao ler os seus livros: "a) cenário e realidade sertaneja: 1 ponto; b) enredo: 2 pontos; c) poesia: 3 pontos; d) valor metafísico-religioso: 4 pontos" (ROSA, 2003b, p. 90-91). Obviamente, o escritor mineiro esclarece que tal declaração consubstanciava-se tão somente num manifesto de intenções, pois tinha clareza de que quando suas estórias ganhassem o mundo, receberiam as mais diversas e controversas interpretações, sobre as quais ele não teria controle algum, como se pode constatar pela farta e inumerável fortuna crítica que se construiu sobre sua literatura ao longo dos anos. Entretanto, para o que este artigo se propõe, a gradativa pontuação que Rosa desvelou sobre sua obra, se converte na melhor trajetória para aproximar-me da composição de sua linguagem e, em decorrência, de sua metafísica.

É por mero recurso didático e retórico que este artigo tem como título "Linguagem e metafísica em João Guimarães Rosa", pois que é simplesmente impossível separar essas duas criações humanas quando se trata do escritor mineiro. A poesia, ou seja, a linguagem criptografada rosiana, manifesta simbólica e constantemente um outro âmbito, a saber, o metafísico-religioso, tão caro ao escritor. A simbiose entre a linguagem e a metafísica rosiana pode ser traduzida por essa enigmática afirmativa: "são vaguezas intencionais, personagens e autor querendo subir à poesia e à metafísica, juntas, ou, com uma e outra como asas, ascender a incapturáveis planos místicos" (ROSA, 2003b, p. 38). Assim como para Kierkegaard e Unamuno, a linguagem 
para Rosa é transporte para a transcendência, daí que sua concepção de linguagem não poder ser pautada pela via de uma lógica universalizante ou por meio de uma razão totalizadora, mas por uma verve embebida de devaneio, de sonho, de inconsciência e, porque não dizer, de uma certa dose de irracionalidade, de acordo com essa revelação feita a Bizzarri:

Quero afirmar [...] que, quando escrevi, não foi partindo de pressupostos intelectualizantes, nem cumprindo nenhum planejamento cerebral deliberado. Ao contrário, tudo, ou quase tudo, foi efervescência de caos, trabalho quase "mediúmnico" e elaboração subconsciente. Depois, então, do livro pronto e publicado, vim achando nele muita coisa; às vezes, coisas que se haviam urdido por si mesmas, muito milagrosamente. Muita coisa dele, livro, e muita coisa de mim mesmo. Os críticos e analistas descobriram outras que tive que concordar (ROSA, 2003b, p. 89-90).

Em outro momento, ele reitera: "Eu, quando escrevo um livro, vou fazendo como se o estivesse 'traduzindo', de algum alto original, existente alhures, no mundo astral ou no 'plano das ideias', dos arquétipos, por exemplo. Nunca sei se estou acertando ou falhando, nessa 'tradução"' (ROSA, 2003b, p. 99).

Mencionei no final do primeiro tópico deste artigo que Rosa, mediante seu diligente trabalho literário, criou um monumento de "literatura-vida" (ROSA, 2003b, p. 99). Ressalvo que quando digo trabalho diligente não me refiro a uma mera força de expressão, conforme o autor bem o descreve:

Apenas sou incorrigivelmente pelo melhorar e aperfeiçoar, sem descanso, e em ação repetida, dorida, feroz, sem cessar, até o último momento, a todo custo. Faço isso com os meus livros. Neles, não há nem um momento de inércia. Nenhuma preguiça! Tudo é retrabalhado, repensado, calculado, rezado, refiltrado, refervido, recongelado, descongelado, purgado, reengrossado, outra vez filtrado (ROSA, 2003a, p. 234).

O termo "monumento", inclusive, talvez não seja o mais adequado para exprimir a dinâmica que o encontro dessas duas expressões humanas implica na obra rosiana, tanto para ele como o seu criador, quanto para quem tem o privilégio de lê-la e analisá-la. Nesse aspecto, outra vez, Kierkegaard, Unamuno e Rosa se aproximam em seus processos criativos. O filósofo dinamarquês, quando, por meio de uma linguagem incomum, busca dar um salto nas divisas entre filosofia, literatura e teologia, de modo a alcançar a verdade que seja a verdade para ele, a ideia pela qual quer viver e morrer. No caso do pensador espanhol, quando opta pela ficção como via de exposição de seu pensamento, posto que, mediante esse subterfúgio, escapa à elucubração meramente intelectual e retórica, no momento em que dá vida a seus personagens e deixa que eles encarnem com a profundidade e a sinceridade necessárias a sua própria palavra, como ele mesmo, de forma divertida, esclarece: "Estoy avergonzado de haber alguna vez fingido entes de ficción, personajes novelescos, para poner en sus lábios lo que no me atrevía a poner en los míos y hacerles decir en broma lo que yo siento muy a serio" (UNAMUNO apud MIRAMÓN, 1986, p. 11). E Rosa particulariza a sua relação entre literatura e vida da seguinte maneira:

sou profundamente, essencialmente religioso, ainda que fora do rótulo estricto e das fileiras de qualquer confissão ou seita; antes, talvez, como o Riobaldo do 'G.S. : V', pertença eu a todas. E especulativo, demais. Daí, todas as minhas, constantes, preocupações religiosas, metafísicas, embeberem meus livros (ROSA, 2003b, p. 90).

Como se pode notar, é pela mediação de uma enredada tessitura da linguagem que Rosa infiltra o seu pendor pela metafísica nas estórias que narra. Estórias essas que só aparentemente se conformam em destinos, peripécias, acidentes, acontecimentos, casos, circunstâncias, dificuldades, episódios, imprevistos e incidentes por que passam os/as inúmeros/as perso- 
nagens de seus contos, novelas e romance. Porém, cada estória, cada personagem e cada evento ao qual estão submetidos, resguardam um registro simbólico, um desafio enigmático, a manifestação da estranheza, a emergência de um paradoxo, concordante com uma espécie de mapa de leitura que ele prescreveu a Meyer-Clason:

Em geral, quase toda frase minha tem de ser meditada. Quase todas, mesmo as aparentemente curtas, simplórias, comezinhas, trazem em si algo de meditação ou de aventura. Às vezes, juntas, as duas coisas, aventuras e meditação. Uma pequena dialética religiosa, uma utilização, às vezes, do paradoxo; [...] nos planos, que sempre se interseccionam, da poesia e da metafísica (ROSA, 2003a, p. 238-239).

Se é o caso de aproximar Rosa da figura do filósofo, como este artigo busca fazer em forma de negaça, não é por outra trilha senão a da linguagem, e esta, como já exposto, imantada de metafísica, assim como o escritor fez por valer com esforço incomparável, haja vista o tempo despendido para a escrita de seus livros, como pode ser observado pelo intervalo de publicação entre um e outro: Sagarana, em 1946; dez anos depois, em 1956, vem a público dois calhamaços, Corpo de baile 3 e Grande sertão: veredas; em 1962, sai Primeiras estórias, e, em 1967, é publicado seu último livro em vida, Tutameia (Terceiras estórias) ${ }^{4}$. A preocupação do escritor, como fica evidente, não era com uma literatura feita às pressas, com prazo de entrega preestabelecido, o seu compromisso era com a criação de uma literatura enquanto advento para uma permanente leitura e releitura, para um constante pensar e repensar, para uma incansável meditação, condizente com o que ele instruiu Meyer-Clason, quando este traduzia o conto Partida do audaz navegante (ROSA, 2001, p. 166-175) de Primeiras estórias para a língua alemã:

Duas coisas convêm ter sempre presente: tudo vai para a poesia, o lugar-comum deve ter proibida a entrada, estamos é descobrindo novos territórios do sentir, do pensar, e da expressividade; as palavras valem 'sozinhas'. Cada uma por si, com sua carga própria, independentes, e às combinações delas permitem-se todas as variantes e variedades (ROSA, 2003b, p. 314).

Descobrir novos territórios para a prontidão do sentimento, para o exercício do pensamento e para a eclosão de diversos modos de expressão: não há melhor tradução da maneira rosiana de filosofar e de habitar a filosofia, considerando sempre esse âmbito de busca pelo saber, melhor dizendo, de busca pela sabedoria, como uma humana ambição metafísica, pois, de acordo com o criador de Riobaldo e Diadorim: "Cada pessoa é apenas o portador (neste mundo) de uma mensagem (desconhecida) [...] todos nós, somos não mais que um símbolo para significar algo que nós mesmos não sabemos o que seja" (ROSA, 2003a, p. 341).

Embora, penso eu, tenha ficado clara a magnitude do que significa a expressão, com vocação para aforismo, declarada por Rosa de que "sua missão mais importante: é o próprio homem" (ROSA, 2003a, p. 341), acredito que se faça necessário retomá-la, de modo a não deixar pairar sombra de dúvida de que a sua linguagem e, consequentemente, a sua metafísica, a despeito da forma obscura de como se apresentam, não procuram se posicionar numa esfera distanciada do humano, muito antes pelo contrário, para o escritor mineiro, o humano vem antes e a linguagem, depois. É precisamente nesse ponto que as mãos da linguagem e da metafísica rosiana bordejam a filosofia com leme seguro, pois, consoante Meyer-Clason registrou no posfácio da edição alemã de Primeiras estórias,

\footnotetext{
${ }^{3}$ A primeira edição de Corpo de baile, um conjunto de sete novelas, foi lançada em dois volumes. Em sua segunda edição, em 1960, a obra foi relançada em um só volume. A partir de sua terceira edição, foi subdivida em três novos volumes: Manuelzão e Miguilim, em 1964; No Urubuquaquá, No pinhém e Noites do sertão, em 1965.

${ }^{4}$ Postumamente foram publicadas as seguintes obras: Estas estórias, em 1969, e Ave, palavra, em 1970.
} 
[Rosa] não procura a realidade na própria linguagem, ele procura com ela perscrutar através da linguagem a realidade humana. Para Rosa, a linguagem não é um substituto do homem, mas o meio de torná-lo visível, pensável, perceptível e palpável. [...] em Rosa, o homem e a linguagem são um. Ou expressando de outro modo: a linguagem não retorna para si de mãos vazias. Ela é o veículo, o portador, a expressão, o instrumento (MEYER-CLASON apud ROSA, 2003a, p. 410).

Ou ainda, nas palavras do próprio Rosa: "A língua, para mim, é instrumento: fino, hábil, agudo, abarcável, penetrável, sempre perfectível, etc. Mas sempre a serviço do homem e de Deus, do homem de Deus, da Transcendência" (ROSA, 2003a, p. 412b).

Eis, então, a revelação da metafísica rosiana: a sua linguagem se consubstancia num artefato que está em sintonia fina com a Transcendência, e aqui eu faço um destaque: "a serviço do homem e de Deus, do homem de Deus". Em outras palavras, trata-se de uma linguagem que serve ao humano, mas também serve a Deus. É linguagem que o humano dirige a Deus enquanto sua criatura, mas é também linguagem que Deus dirige ao homem, enquanto seu Criador; porém, e, acima de tudo, é linguagem que o humano cria apesar e a despeito de ser criatura de Deus; é linguagem que, portanto, cria outros e novos universos, cria outros e novos humanos, pois trata-se de o escritor fazer-se demiurgo para medir força com seu próprio Criador. Se, para Unamuno, replicando Calderón de La Barca, somos um sonho de Deus; para Rosa, sendo um sonho sonhado por Deus, podemos sonhar outros e novos sonhos, enquanto Ele dorme o seu divino sono. É dessa forma que Rosa destrona uma possível acusação, demasiado equivocada, de ter construído uma metafísica complacente e impassível, pois, segundo ele, essa linguagem que se lança ao Transcendente,

No fundo é um conceito blasfemo, já que assim se coloca o homem no papel de amo da criação. O homem ao dizer: eu quero, eu posso, eu devo, ao se impor isso a si mesmo, domina a realidade da criação. Eu procedo assim, como um cientista que também não avança simplesmente com a fé e com pensamentos agradáveis a Deus. Nós, o cientista e eu, devemos encarar a Deus e o infinito, pedir-lhes conta, e, quando necessário, corrigi-los também, se quisermos ajudar o homem. Seu método é o meu método. [...]. Meditando sobre as palavras, [o homem] descobre a si mesmo. Com isto repete o processo da criação. Disseram-me que isto era blasfemo, mas eu sustento o contrário. Sim! A língua dá ao escritor a possibilidade de servir a Deus corrigindo-o (ROSA apud LORENZ, 1973, p. 340).

Talvez seja chegado o momento de eu expor, ainda que sumariamente, os aspectos constituidores da linguagem rosiana que a matizam de elementos metafísicos. Antes de mais nada, como foi aludido anteriormente, a língua, para Rosa, é o seu "elemento metafísico" (ROSA apud LORENZ, 1973, p. 340). Ao atribuir à língua tal emblemática característica, fez com que o escritor se revestisse, em relação a ela, com a autoridade de um alquimista, triturando-a, destilando-a, coagulando-a, fundindo-a, refinando-a, posto que, para ele, “Escrever é um processo químico; o escritor deve ser um alquimista. Naturalmente, pode explodir no ar. A alquimia do escrever precisa de sangue do coração" (ROSA apud LORENZ, 1973, p. 341). A partir dessa esotérica fórmula, foi que Rosa lidou com a língua. Por exemplo, ao reelaborar inúmeras peculiaridades da filologia latino-americana, advindas do português e do espanhol arcaicos, que, uma vez embebidas de elementos transcendentes, interditaram o seu acesso pelo exercício da pura razão. Há que se ressaltar, sobremodo, a sua obsessão na utilização de cada palavra como se, às avessas, ela estivesse em estado de parto de seu significado primevo, libertada, pois, da crosta repetida e irrelevante de seu uso cotidiano. Sobre essa obsessão, ele declara sem o menor pudor:

Não sou um revolucionário da língua. Quem afirme isto não tem qualquer sentido da língua, pois julga segundo as aparências. Se tem de haver uma frase feita, eu preferia que 
me chamassem reacionário da língua, pois quero voltar cada dia à origem da língua, lá onde a palavra ainda está nas entranhas da alma, para poder lhe dar luz segundo minha imagem (ROSA apud LORENZ, 1973, p. 341).

Outro aspecto do qual não se pode descurar é a recuperação que Rosa opera, pela nuança da escrita literária, do linguajar do povo de sua região, quando, na sua infância em Cordisburgo, sentado diante do comércio de seu pai, seu Floduardo, ouvia com devotada atenção as narrativas lendárias e míticas dos vaqueiros, dos vendedores ambulantes, dos tropeiros, dos pregadores, em forma de contos, casos e canções; fato esse confirmado como corriqueiro por sua memorabilia: "Deus meu! No sertão, o que pode uma pessoa fazer do seu tempo livre a não ser contar estórias? A única diferença é simplesmente que eu, em vez de contá-las, escrevia" (ROSA apud LORENZ, 1973, p. 325). Não se pode esquecer, por sua vez, que Rosa, embora fosse um escritor que escrutinasse incansavelmente a ascendência das palavras, era um autor da modernidade, alinhado ao seu período histórico, o que fazia dele, por todas as razões aqui apresentadas, um experimentador incansável da língua, assim como eram alguns/mas outros/as escritores/as e poetas de seu contexto literário. Por fim, e não menos importante, é preciso colocar em relevo o fato de Rosa ter sido um poliglota, um estudioso e pesquisador atento e voraz de várias línguas ${ }^{5}$, prodígio esse que o predispôs à criação de neologismos e de improváveis reordenações sintáticas em sua produção literária. Eis, em poucas linhas, como ele traduz o seu afazer poético-metafísico: "As aventuras não têm tempo, não têm princípio nem fim. E meus livros são aventuras; para mim, são minha maior aventura. Escrevendo descubro sempre um novo pedaço de infinito. Vivo no infinito; o momento não conta" (ROSA apud LORENZ, 1973, p. 328).

Após esse custoso périplo pelos meandros labirínticos da linguagem e da metafísica rosiana, é possível afirmar que o escritor mineiro estaria de alguma maneira fronteiriço à figura do filósofo? É viável asseverar que sua elaboração literária bordeja um modo de fazer filosofia ou de filosofar? Embora as declarações de Rosa revelem que tais questões não teriam a menor importância no seu rol de preocupações, e que, portanto, para ele, seria uma discussão irrelevante; a minha aposta e, como é sabido, quem aceita uma aposta se expõe ao risco de ganhar ou perder, é a de que, e aí vai a minha ressalva, à maneira de Kierkegaard e de Unamumo, o "arquiteto da alma" nascido em Cordisburgo, na condição de escritor, fez de sua obra um manancial de aventuras, cujos símbolos e metáforas que delas borbulham, misturados no cadinho da metafísica, dão muito o que pensar e repensar. Mas o pensamento especulativo de que resulta a leitura de seus livros não se esgota na experiência estética por ela proporcionada. Para além disso, há um incômodo que mobiliza o/a leitor/a para a experiência ética, para uma nova maneira de ser e agir e, consequentemente, para um desejo de mudar o mundo. Se isso não é um jeito astucioso de se fazer filosofia ou de filosofar, não tenho, então, a menor ideia do que seja essa matéria. Sei bem que talvez nessa aposta eu esteja blefando muito alto, mas vou nomear esse blefe de utopia, uma utopia literária na qual acredito profundamente, seguindo os passos do Magister Rosa quando declara: "Como escritor tento o impossível" (ROSA apud LORENZ, 1973, p. 333). No entanto, para não deixar essa frase com ares de cabotinagem da parte de Rosa, associo-a a esta outra passagem, por ele também pronunciada:

\footnotetext{
${ }^{5}$ Conforme Lorenz (1973, p. 339), “Por um artigo publicado no Brasil em 1967, após a morte de Guimarães Rosa, eu soube que ele falava português, espanhol, francês, inglês, alemão e italiano. Além disso, possuía conhecimentos suficientes para ler livros em latim, grego clássico, grego moderno, sueco, dinamarquês, servo-croata, russo, húngaro, persa, chinês, japonês, hindu, árabe e malaio".
} 
Legítima literatura deve ser vida. Não há nada mais terrível que uma literatura de papel, pois acredito que a literatura só pode nascer da vida, que ela tem de ser a voz daquilo que eu chamo de "compromisso do coração". A literatura tem de ser vida! O escritor deve ser o que ele escreve (ROSA apud LORENZ, 1973, p. 330).

\section{"A poesia medra com raizinhas no absurdo..."}

À guisa de conclusão deste artigo, escolhi, como subtítulo, uma frase que Rosa sugeriu a Meyer-Clason, como sendo a que possuía o sentido mais aproximado, em português, de um trecho do já mencionado conto

Partida do audaz navegante", que o tradutor buscava verter para o alemão. O propósito de eu tê-la fisgado em meio a tantas outras, qual um paciente e experiente pescador o faz em relação ao peixe que tem mais valor, foi em razão de tal frase: "A poesia medra com raizinhas no absurdo [...] (ROSA, 2003a. p. 316),

insinuar e indiciar algo de máxima, de provérbio, de aforismo, de sentença, que vem à tona após um longo mergulho no rio da linguagem metafísica rosiana: "Sim, diria o escritor mineiro, rio é uma palavra mágica para conjugar eternidade" (ROSA apud LORENZ, 1973, p. 329). À maneira de um audaz navegante, ouso, então, singrar tal rio para tentar elucidar o que sustenta a ideia do autor de GSV, ao declarar que, como escritor, tenta o impossível.

A começar pelo próprio paradoxo de a palavra absurdo ser a característica de algo privado de sentido, há uma série de outros significados que acumulam negativamente esse termo, desde os mais corriqueiros aos mais herméticos: aquilo que carece de racionalidade; coisa que não está adequada a determinada regra ou padrão; aspecto do que é antagônico à sensatez; característica de uma existência sem razão de ser; aparência do devaneio, do sonho, da irrealização; manifestação da falta de lógica, e, conforme Abbagnano, “Em sentido mais restrito e preciso, essa palavra significa 'impossível' [...] porque contraditório" (ABBAGNANO, 1998, p. 7). Tentar o impossível, como se pode observar, é, contraditoriamente, fazer com que a linguagem seja engendrada a partir e apesar de todos os significados implicados no termo absurdo, ou seja, é tomá-la como irracional, inadequada, insensata, ilógica, irrealizável e, paradoxalmente, factível. É sob a perspectiva de sua própria impossibilidade que a poesia nasce e cresce enraizando-se no absurdo, assim como Rosa põe à prova, mediante a sua literatura, ao concebê-la desde uma linguagem cuja criação e captação exige ao/à escritor/a e ao/à leitor/a uma sintonia de outro nível, congruente com uma réplica que ele fez a Lorenz: "Existem elementos da língua que não são captados pela razão; para eles são necessárias outras antenas" (ROSA apud LORENZ, 1973, p. 348). Tentar o impossível do modo que Rosa se lança à linguagem, não é sucumbir diante dos obstáculos de sua irrealização, é diligentemente trabalhá-la até que ela confesse o que realmente tem a dizer. É esforçar-se na busca por reencontrar o seu caroço, após anos e anos ter sido revestida de várias camadas de significados irrisórios. É, a despeito da negativa constante do inatingível, empreender meios os mais diversos de executá-la, ensaiando-a, testando-a, experimentando-a, provando-a. É não subestimar a capacidade humana de criar, recriar, entender e compreender, instigada insistentemente por uma vontade de saber sempre mais e melhor. É envidar a deixar-se seduzir, a perder-se em vertiginosa queda ou subida em/para outros tempos e espaços. É expor-se ao mal e ao bem, arriscar-se à fortuna ou ao azar, aventurar-se por veredas nunca antes percorridas. E o mais importante, tentar o impossível, à vista do que foi exposto, não é só o esforço humano de realizar algo que já se sabe de antemão irrealizável; tentar o impossível é, sobretudo, fazer com que o impossível caia em tentação, é tentá-lo de tal maneira que ele su- 
cumba ao desejo de realizar a si mesmo, tornando-se visível em sua plenitude, manifestando-se em toda sua glória. É exatamente neste ponto que o absurdo é vencido por uma palavrinha composta por duas letras, cujo estranho poder faz com que ele seja virado do avesso, e, milagrosamente, aquilo que era obscuro, opaco e velado, faz-se transparente, claro, epifânico.

Não vou revelar, de forma gratuita o nome dessa palavrinha que possui o condão de fazer frente ao absurdo a ponto de desnudá-lo, vou deixá-la na forma de um pequeno enigma a ser desvendado pelo/a o/ meu/minha possível leitor/a na passagem a seguir, que trata da lenda do "fogueteiro", narrada no capítulo 23 de Niebla, de Unamuno, aquele que bem poderia ter sido o "avô" de Rosa:

María, una joven ciega, se encuentra perdida cuando recobra la vista porque no puede hallar el caminho que recorría a diário estando ciega, y necessita vendarse de nuevo los ojos. La protagonista viene a simbolizar la fe, [...] expressa la desorientación del hombre en el mundo cuando carece de fe (MIRAMÓN, 1986, p. 13).

\section{Referências}

ABBAGNANO, N. Dicionário de filosofia. Trad. A. Bosi. 2. ed. São Paulo: Martins Fontes, 1998.

AMARAL, R. Guimarães Rosa e Marcuse: a literatura como resistência política. Humanidades \& Inovação, v. 6, 2019. p. 35-45.

AMARAL, R. Todos os homens são filósofos. Riobaldo é homem. Logo, Riobaldo é filósofo. Interfacis, v. 2, 2016a. p. 36-47.

AMARAL, R. A narrativa rosiana: o verbo do sertão. Humanidades \& Inovação, v. 3, n. 3, 2016c. p. 7-22.

AMARAL, R. A questão do mal em Grande Sertão: Veredas - Um diálogo entre Tomás de Aquino e o jagunço Riobaldo. Em Tese, v. 22, 2016c. p. 21-30.

AMARAL, R. A inovação semântica ricoeuriana em Grande Sertão: Veredas. Prometeus, v. 12, 2013. p. 273-281.

AMARAL, R. As aparências de Cronos em Grande Sertão: Veredas. Kuruatuba, v. 1, 2011a. p. 06-15.

AMARAL, R. A questão do narrador: Walter Benjamin e Guimarães Rosa. Araticum, v. 4, 2011 b. p. 52-61.

AMARAL, R. A teofania em Grande sertão: veredas - por uma pedagogia dos símbolos. Goiânia. 143f. Tese (Doutorado em Educação). Universidade Federal de Goiás, 2007.

AMARAL, R. "Viver é muito perigoso" ou o "mal" em Grande sertão: veredas - breves anotações tomistas. Cadernos de pesquisa do CDHIS, v. 34, n. 19, 2006a. p. 36-44.

AMARAL, R. O imaginário em Grande sertão: veredas - a travessia do Liso do Sussuarão. Revista Labirinto, v. VI, n. 9, 2006b.

CONCHE, M. Introdução. In: HUISMAN, D. Dicionário dos filósofos. São Paulo: Martins Fontes, 2001. D'HONT, J. Hegel. In: HUISMAN, D. Dicionário dos filósofos. São Paulo: Martins Fontes, 2001. GUIMARÃES, V. Joãozito - infância de João Guimarães Rosa. Rio de Janeiro: J. Olympio, 1972. KEMP, P. Kierkegaard. In: HUISMAN, D. Dicionário dos filósofos. São Paulo: Martins Fontes, 2001. LORENZ, G. João Guimarães Rosa. In: LORENZ, G. Diálogo com a América Latina. Panorama de uma literatura do futuro. São Paulo: E.P.U., 1973. 
MIRAMÓN, A. Introducción. In: UNAMUNO, M. Niebla. Madrid: Alianza, 1986.

MORAIS, K; AMARAL, R. A questão do mal em Grande sertão: veredas - uma leitura à luz da hermenêutica de Paul Ricoeur. Humanidades \& Inovação, v. 6, 2019. p. 73-96.

ROSA, J. G. Primeiras estórias. 15. ed. Rio de Janeiro: Nova Fronteira, 2001.

ROSA, J. G. Correspondência com seu tradutor alemão Curt Meyer-Clason (1958-1967). Trad. E. Paschoal. Rio de Janeiro: Nova Fronteira; Academia Brasileira de Letras; Belo Horizonte: EDUFMG, 2003a.

ROSA, J. G. Correspondência com seu tradutor italiano Edoardo Bizzarri. 3. ed. Rio de Janeiro: Editora da UFMG; Nova Fronteira, 2003b.

ROSA, J. G. Grande Sertão: Veredas. 19. ed. Rio de Janeiro: Nova Fronteira, 2001.

SAVATER, F. Prólogo. Em: UNAMUNO, M. Do sentimento trágico da vida - nos homens e nos povos. Trad. E. Brandão. São Paulo: Martins Fontes, 1996.

\section{Sobre o autor}

\section{Roberto Antônio Penedo do Amaral}

Doutor em Educação pela Universidade Federal de Goiás (UFG). Professor do Curso de Licenciatura em Filosofia e do Programa de Mestrado Profissional em Filosofia (PROFILO) da Universidade Federal do Tocantins (UFT). 